\title{
A gastrointestinalis traktusból migrált, lenyelt idegen testek esetei
}

\author{
Balázs Ákos dr. ${ }^{1}$ - Vass Tamás dr. ${ }^{1}$ \\ Tárnoki Dávid dr. ${ }^{2}$ - Baranyai Zsolt dr. ${ }^{1}$
}

Semmelweis Egyetem, Általános Orvostudományi Kar, I. Sebészeti Klinika, Budapest

${ }^{2}$ Semmelweis Egyetem, Általános Orvostudományi Kar, Radiológiai Klinika, Budapest

\begin{abstract}
A lenyelt idegen test gastrointestinalis traktusból való kilépése és migrációja az idegentest-nyelések számához képest ritka jelenség. Bemutatott két esetünkben a súlyos szeptikus állapot sürgős sebészeti beavatkozást igényelt. Az egyik esetben a máj állományába és a retroperitoneumba, a másik esetben a máj bal lebenyén keresztül a pericardiumba hatoltak a hónapokkal korábban lenyelt drótdarabok. Első esetünknél a retroperitoneumban, majd a femoralis régióban, a második esetnél a máj és pericardium területén észleltünk a feltárás során suppurativ szövődményt. Az extrakció után első esetünkben ismételt mútétre kényszerültünk a retroperitonealis phlegmonének a femoralis régióra terjedése miatt. A tályogrendszerek kiürítése után mindkét esetben gyógyulást sikerült elérnünk. Az esetek diagnosztikus problémái tanulságosak a mindennapi gyakorlat számára.
\end{abstract}

Orv Hetil. 2019; 160(42): 1677-1681.

Kulcsszavak: lenyelt idegen testek, migráló idegen test, szövődmények

\section{Cases of migration of swallowed foreign bodies from the gastrointestinal tract}

Migration of swallowed foreign bodies from the gastrointestinal tract is a rare phenomenon compared with the total number of ingestions. In the reported two cases, the serious septic condition indicated urgent surgical intervention. We found a piece of wire swallowed a few months earlier in the right lobe of the liver and the retroperitoneum in case one, and a piece of wire in the pericardium, which migrated from the stomach through the left lobe of the liver, in case two. Abscesses and phlegmonae were found in the retroperitoneum and then in the femoral region requiring a reoperation in case one, and in the liver and pericardium in case two. After the evacuation of abscesses, both patients made full recovery. Diagnostic difficulties and therapeutic challenges served the reasons to present these cases.

Keywords: swallowed foreign bodies, migration of foreign body, complications

Balázs Á, Vass T, Tárnoki D, Baranyai Zs. [Cases of migration of swallowed foreign bodies from the gastrointestinal tract]. Orv Hetil. 2019; 160(42): 1677-1681.

(Beérkezett: 2019. május 5.; elfogadva: 2019. május 18.)

\section{Rövidítések}

$\mathrm{CRP}$ = C-reaktív fehérje; CT = (computed tomography) számítógépes tomográfia; $\mathrm{EKG}=$ elektrokardiográfia; $\mathrm{MR}=($ mag netic resonance) mágneses rezonancia

A gastrointestinalis traktust endoszkóppal vizsgálók nagy része múzeumba illő gyújteménnyel rendelkezik a lenyelt és sikeresen eltávolított, esetenként igen meglepő idegen testekből. Az idegen test lenyelését gyermekek játék közben véletlenszerúen, felnőttek baleseti jelleggel, szuicid szándékkal, mentálisan sérült tudattal (pszichiátriai kórképekben, mentális retardációban, szenilis dementiában szenvedők) és gyakorta a büntetés-végrehajtás alóli kibúvás okán követik el [1-3]. A lenyelt idegen testek $80 \%$-a spontán, tünetmentesen, per vias naturales távozik. 20\%-ukban, az elakadó és szövődmény lehetőségét magában hordozó esetekben szükséges az eltávolítás. Az eltávolítás többnyire endoszkópos úton lehetséges és biztonságos; csak az esetek 1\%-ában szükséges sebészeti 
úton beavatkozni, az endoszkópos lehetőség kivitelezhetetlensége, veszélye vagy a kialakult szövődmény ellátása miatt $[2,4,5]$.

A lenyelt idegen test gastrointestinalis traktusból való migrációja az idegentest-nyelések jelentős gyakoriságához képest ritka jelenség, különösen, ha ez több, egy időben lenyelt idegen testet jelent. Az idegentest-nyelés és -migráció következtében kialakuló állapot számos diagnosztikus és terápiás problémát okoz, mind az állapot felismerése, mind az idegen test eltávolítása és a kialakult szövődmények kezelésének vonatkozásában.

\section{Esetismertetés}

\section{Elsö eset}

A 46 éves férfi beteg kórelőzményében a büntetés-végrehajtási intézetben való tartózkodása során, a megelőző két évben, ismételten lenyelt idegen testek miatt végzett mütétek szerepeltek. A jelenlegi problémát okozó 8,10 és $14 \mathrm{~cm}$ hosszú, 1,5 mm vastag drótot egy hónappal korábban nyelte le. Felvételét megelőzően két héttel, akut hasi katasztrófa képe miatt a büntetés-végrehajtás sebészeti osztályán végzett mütét során a retroperitoneum területéról $8 \mathrm{~cm}$-es drótdarabot távolítottak el. További idegen testet a kismedencében, gyulladásos konglomerátummal körülvetten tapintottak, de technikai feltételek hiányában ennek eltávolítása nem történhetett meg. Romló szeptikus állapot miatt került klinikánkra. Vizsgálatakor diffúz hasi és bal costolumbalis érzékenységet, meteorismust, renyhe perisztaltikát ész-

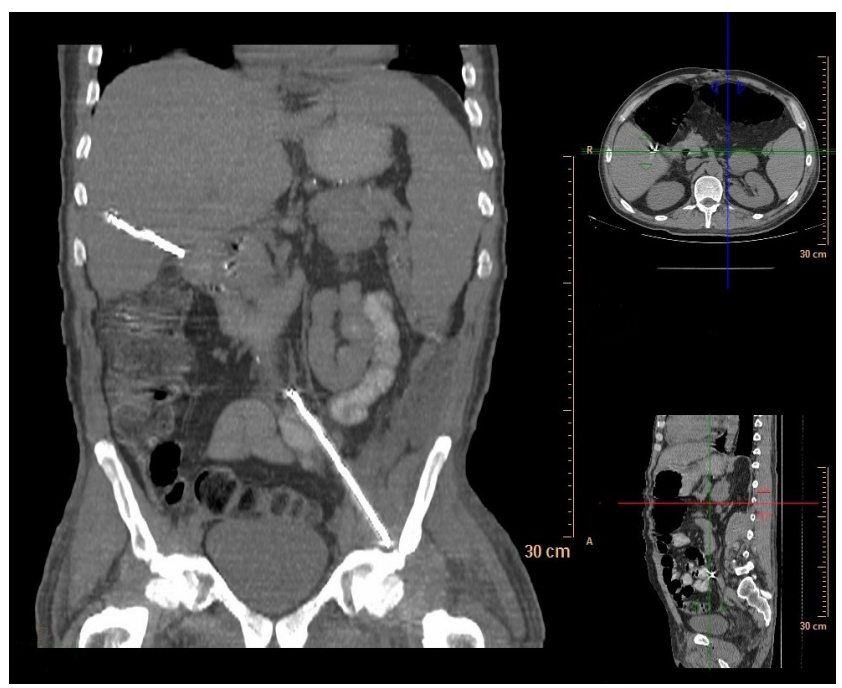

\begin{tabular}{l|l} 
1. ábra & Fémdenzitású idegen test a duodenum bulbusától a máj jobb
\end{tabular} lebenyébe követhetően és a bal retroperitoneumban. Az intrahepaticus epeutakban levegó ábrázolódik. A retroperitonealis idegen test környezetében abscessus mutatható ki. 1. eset, koronális rekonstrukciós CT-felvétel (MIP, 7 mm, Philips Brilliance 16)

$\mathrm{CT}=$ számítógépes tomográfia; $\mathrm{MIP}=$ maximális intenzitású projekció

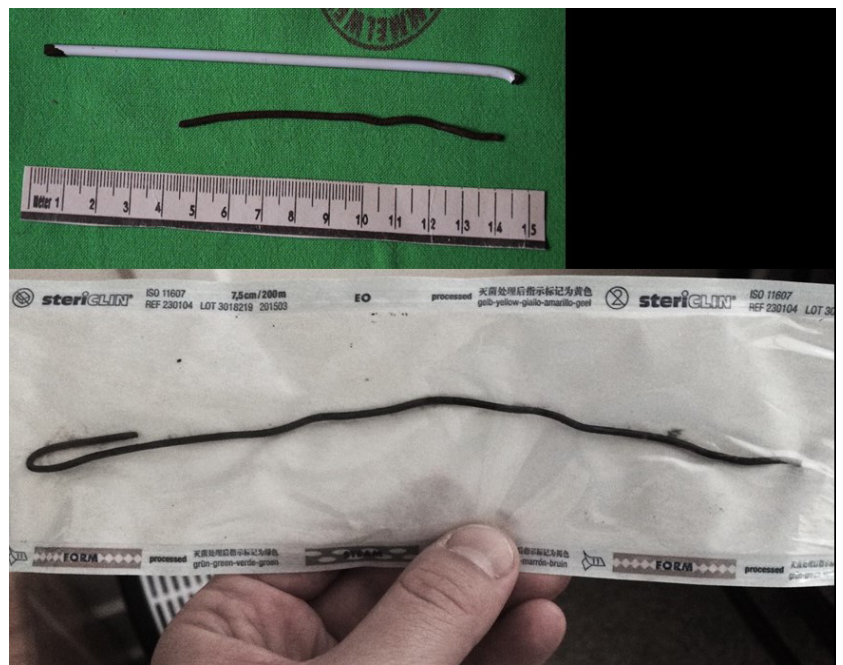

2. ábra

Az eltávolított idegen testek. Felülről az első a retroperitoneum ból eltávolított $14 \mathrm{~cm}$ hosszú, múanyag bevonatú drót (1. eset) Felülről a második a máj jobb lebenyéból eltávolított $10 \mathrm{~cm}$-es drót (1. eset). A legalsó a gyomorból a pericardiumba érő, 23 cm hosszú, visszahajlított végú drót (2. eset)

leltünk. A bal comb az ellenoldalihoz képest nagyobb körfogatú, a perifériás pulzusok jól tapinthatók voltak. Laborvizsgálata során anaemiát, leukopeniát, thrombocytopeniát, emelkedett májfunkciós értékeket, magas CRP-értéket, az ionháztartás eltéréseit, valamint acidózist találtunk. Mellkasi és natív hasi röntgenvizsgálattal szabad hasi levegőt nem észleltünk, a jobb subhepaticus régióban és a bal alhas területén fémintenzitású, árnyékot adó idegen testeket láthattunk. A magával hozott, néhány órával korábban készült CT-felvételen (1. ábra) a máj jobb lebenyében $10 \mathrm{~cm}$-es és az aortabifurkáció pontjától a csípőcsontig követhető, 14 cm hosszú második idegen test volt látható. Gyors előkészítést követően mútétet végeztünk. A hasfal mögött és interintestinalisan purulens tartalmú folyadékot találtunk, mely a kismedence bal oldala irányából ürült. A jobb subhepaticus régióban szívós összenövések között a duodenum felső könyöke és a jobb májlebeny között sipolyjárat nyílt meg. A járat máj felőli végében jelentősen korrodált drót vége volt fellelhető, mely jobbra, ferdén felfelé, teljes egészében a parenchymában helyezkedett el. A 10 centiméteres drót eltávolítása után a járatból epe-, vér- vagy egyéb kóros váladék nem ürült (a 2. ábrán felülról a második idegen test). A doudenumon lévő sipolynyílást egy rétegben, csomós öltésekkel zártuk. A vékonybelek adhézióinak szétválasztása közben purulens gyülemeket ürítettünk ki. Retroperitonealis helyzetben, az aortaoszlástól ferdén bal felé terjedve találtuk meg a második idegen testet, mely $14 \mathrm{~cm}$ hosszú, fehér múanyag bevonatú drót volt, az abscessus üregrendszerében (a 2. ábrán a legfelső idegen test). A hasüreget és a kismedencét alaposan kiöblítettük. C-karos röntgenkészülék segítségével áttekintettük a hasüreget, kizártuk további idegen testek jelenlétét. Drének visszahagyása mellett zártuk a hasüreget. A posztoperatív első napon a beteg általános 


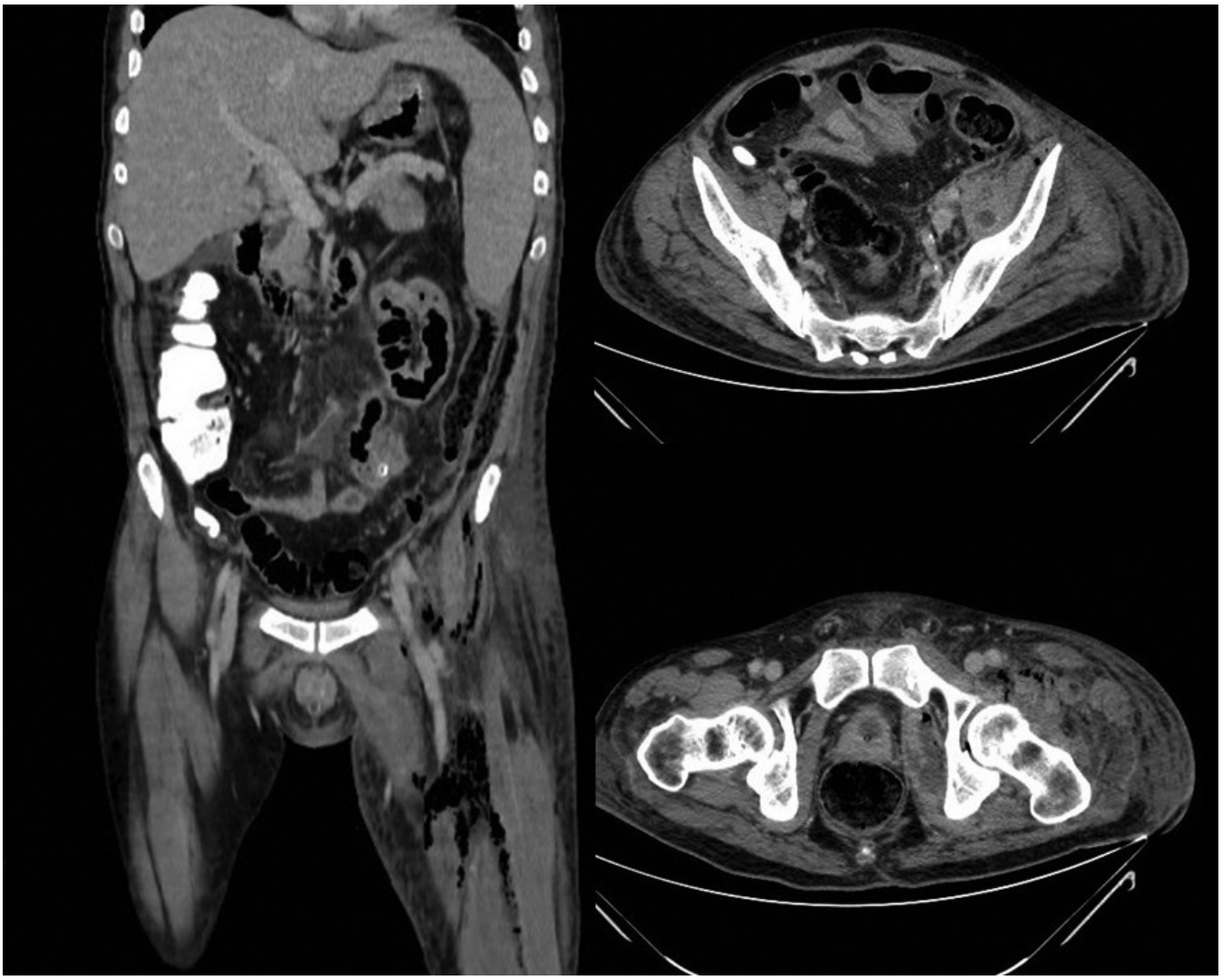

3. ábra

Az 1. esetnél az első posztoperatív napon végzett CT-vizsgálat a bal oldali femoralis régióban kiterjedt tályogrendszer képét mutatta. Koronális és axiális CT-felvételek (Philips Brilliance 16)

CT = számítógépes tomográfia

állapota és laborparaméterei javultak, de lázas volt. Gépi lélegeztetése megszüntethető volt. Új jelenségként a bal alsó végtag megrövidült, és kifelé rotált helyzetét és a korábbiaknál fokozottabb duzzanatát észleltük. A csípőízület radiológiai vizsgálata nem igazolt eltérést, de a lágyrész-környezetben gázárnyékokat mutatott ki. CTvizsgálatot végeztünk, melynek során az iliopsoas mentén, az obturator izomzat között a combtájékra terjedő, a csípőízületet is körülvevő, többrekeszes abscessusrendszer mutatkozott (3. ábra). A bal vena femoralis communisban thrombus látszott. A klinikai kép és a képalkotó vizsgálat eredménye alapján reoperáció mellett döntöttünk. A korábbi behatolás mentén feltárva a hasüreget, a kismedencében, a musculus iliopsoas mentén és a femoralis csatornában a comb felé terjedően találtunk purulens gyülemeket. A comb elülső felszínén további metszést ejtve, az izomrekeszek között necroticus elemeket is tartalmazó, kiterjedt tályogrendszert tártunk fel. A comb lateralis oldalán is feltáró metszésekre kényszerültünk. A feltárt területek alapos átöblítése után a hasüreget drének visszahagyásával zártuk, a femoralis régió sebeit nyitva hagytuk. A váladékok bakteriológiai vizsgálata a Fusobacterium necrophorum, Streptococcus constellatus és anginosus, Lactobacillus spurium, Escherichia coli, Parvimonas micra, Atopobium parvulum törzseket mutatta ki. A leletek beérkezése után az antibioti- kumos kezelést az érzékenységnek megfelelően folytattuk, az induló ceftriaxon + metronidazol kombinációról meropenem + vankomicin terápiára váltva. A beteg állapota fokozatosan javult, a drének szívadéka feltisztult, majd váladékvezetésük megszünt. A posztoperatív 17. napon a küldő sebészeti osztályra további kezelési javaslattal visszahelyeztük.

\section{Második eset}

A 27 éves, büntetés-végrehajtás alatt álló férfi beteg anamnézisében 12 alkalommal fordult elő idegentestnyelés miatt végzett mútéti beavatkozás. Endoszkópos ambulanciánkon is megfordult a megelőző 3 évben, 6 alkalommal fémkanalat, illetve annak nyelét távolítottuk el, szövődménymentesen. A jelenlegi problémát okozó idegen testet 3 hónappal korábban nyelte le; az akkor végzett radiológiai és endoszkópos vizsgálat a duodenumban, rögzült állapotban találta, ezért eltávolítása endoszkópos úton nem volt lehetséges, mütétbe akkor nem egyezett bele. Aktuális panaszai 4 napja kezdődtek, heves mellkasi és felhasi fájdalmakkal, lázzal, hidegrázással, nehézlégzéssel, nagyfokú gyengeséggel. A magával hozott CT-vizsgálati képanyaga nem állt rendelkezésre, a leírásban pericardialis folyadékgyülem, mediastinalis gázzárványok, a nyelőcső alsó szakaszának folytonosság- 


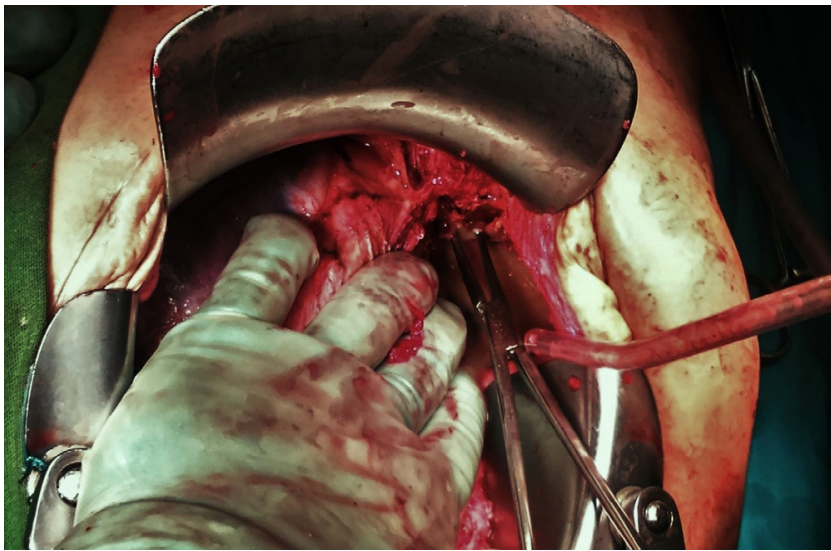

4. ábra

A bal májlebenyen és rekeszizmon keresztülhatoló sipoly a pericardiumba vezet. A pericardiumon nyitott ablakot feltáró esz köz szárai között sűrú purulens tartalom ürül (2. eset, mútét felvétel)

hiánya és a gyomor előtt a szabad hasüregben fémintenzitású idegen test szerepelt. A vizsgáló a nyelőcső perforációjának gyanúját vetette fel. A betegnél sokkos állapotot, mérhetetlen vérnyomást, az EKG-n 'low voltage'-t, súlyos acidózist, hypercapniát észleltünk. A helyszíni mellkasröntgen-vizsgálaton az idegen test aktuális elhelyezkedése nem volt megállapítható. Intenzív előkészítése közben végzett pericardiocentesissel purulens szívadékot kaptunk. A rendelkezésre álló vizsgálati eredményekre támaszkodva sürgôs mütéti beavatkozást végeztünk. Mütétje során a korábbi mütéti hegben kialakult sérvnek megfelelő hasfali hiányon keresztül hatoltunk be. A bal májlebeny és a gyomor közötti lap szerinti összenövéseinek szétválasztásakor az antrumból kiálló, a máj bal lebenyén keresztülhaladó, a rekeszizmon át a pericardiumban végződő drótot találtunk. A májállomány szúrcsatornája és a pericardium ürege purulens izzadmányt tartalmazott (4. ábra). Az idegen testet a gyomorban a kampósan visszahajlított vége rögzítette. A drót eltávolítása után (a 2. ábrán a legalsó idegen test) a gyomor sebét suturával láttuk el, a szúrcsatornát kiöblítettük, a pericardiumot fenesztráltuk, a feltárt területeket drénnel láttuk el. A purulens tartalom bakteriológiai vizsgálata Klebsiella pneumoniae-t mutatott ki; a megkezdett antibiotikumkombináció az érzékenységnek megfelelt, imipenem, gentamicin, flukonazol volt. Intenzív osztályos kezelése mellett állapota stabilizálódott, láztalanná vált, a drének hozama feltisztult, majd megszűnt. Elsődlegesen gyógyuló sebbel, az 5. posztoperatív napon a beutaló intézet sebészeti osztályára visszahelyeztük.

\section{Megbeszélés}

Az idegentest-nyelés következményeit döntően meghatározza a lenyelt tárgy mérete, alakja, a felszín élessége, érdessége, a végződések hegyessége vagy lekerekítettsége, az anyag keménysége vagy rugalmas volta, a kémiai hatása (savas, lúgos vegyhatás), toxikus anyag kibocsátása. Már az idegen test lenyelése kapcsán is létrejöhet a súlyos szeptikus állapothoz vezető sérülés, epiglottis környéki, lateralis és retropharingealis phlegmone, mediastinitis, abszcendáló folyamat [6-8]. Az esetek nagyobb részében az idegen test a lenyelést követően sérülés okozása nélkül továbbhalad, a szövődménymentes esetekben egy héten belül kiürül [4]. Az idegen test időleges elakadása, majd következmények nélküli továbbhaladása is előfordul. Az elakadás leggyakoribb pontjai a nyelőcső élettani szúkületei, a gyomor antruma és a pylorus vonala, a duodenum alsó és felső kanyarulata, a terminalis ileum, a colon flexurái és a rectosigmoidealis átmenet $[2,4$, $5,9]$. Ezeken a pontokon gyakori a perforáció, változatos következményekkel. A nyaki és a mediastinalis szakaszon phlegmone, pyothorax, pulmonalis abscessus, a gastrointestinalis traktus hasi részén az akut hasi katasztrófa klinikai képe jelenhet meg. Előfordul, hogy az idegen test az üreges szerv falába impaktálódik, a nyálkahártya dekubitálódása közben a környezetben (adventitia, zsigeri serosa) gyulladásos folyamat indul, és demarkáció jön létre. A perforáció ezekben az esetekben sipolyképződéssel vagy obtect körülmények között következik be. A sipoly mögöttes szakaszai spontán záródhatnak, míg a haladás irányában kompressziós mechanizmusra kialakuló szöveti necrosis utat nyit a továbbhaladásnak. A perforáció helye ezekben az esetekben a későbbi mútéti eltávolítás során már nem identifikálható [10], hasonlóan 1. esetünkhöz, a retroperitonealis helyzetű drótnál. Az idegen testek tünetszegény módon juthatnak el a kiindulási pontoktól viszonylag távoli helyekre. A nyak régiójában a carotishüvely, a pajzsmirigyállomány, az arteria carotis communis és a vena jugularis együttes laesióját okozó helyzetből, de a nyak bőre alól, a szubkután régióból is távolítottak el lenyelt és elvándorolt idegen testet $[8,11$, 12]. A gyomorból távozó, a májban abscessust okozó lenyelt idegen testről szóló első közlés Lamberttől származik, 1898-ból [13]. Leggieri [5] 2010-ben ismertetett elemzése a máj állományába vándorolt idegen testekról 55 közleményben 59 esetet regisztrált. Henderson lépbe ékelődött, lenyelt idegen testről tett említést [14]. A béltraktusból kilépő és a retroperitoneumba vándorló, 1. esetünkhöz hasonló esetet Hasan [15] közölt. Gül a vékonybél-mesenteriumba vándorolt tüt észlelt [3]. A közlemények nagy részében az idegen test lenyelése és a tünetek jelentkezése között viszonylag hosszú idő telt el. Az általunk eltávolított drótok is erősen korrodáltak voltak (2. ábra). Az ismertetett és elemzett tünetek nem specifikusak [2, 3, 5,9], általában a következményt, a szövődmény jeleit észlelhetjük. A súlyos szeptikus állapot, a beavatkozás sürgőssége, a beteg korlátozott együttmúködése a diagnosztikus lehetőségeket beszükíti, a meglévő adatokra és a mútéti leletre kell a kezelés tervezését alapoznunk. Santos és Leggieri ismertetett eseteiben a májtályog diagnózisával indult kezelés ered- 
ménytelensége utáni mútéti feltárás találta meg a kórfolyamatot okozó idegen testet (csirkecsont, illetve fogpiszkáló). Eseteik tanulsága abban áll, hogy ismeretlen eredetú májtályogok esetén gondolni kell az idegentest-migráció jelenségére $[4,5]$. A lenyelt és spontán távozásra nem alkalmas idegen testeket javasolt a feltalálási helyükról mihamarabb eltávolítani, de ez a beteg együttmúk ödését igényli. A migrált idegen testek sebészi eltávolítására a hagyományos, nyílt műtéti feltárás mellett a laparoszkópos módszer lehetősége is felmerül [2, 4, 5, 9, 16-19]. A tervezéséhez szükséges az idegen test pontos lokalizációjának, a megközelítés lehetőségének és a kialakult szövődménynek az ismerete. Natív és kontrasztanyagos röntgenvizsgálat, CT-, MR-, ultrahangvizsgálat eredményeinek együtt értékelése alkalmas a lokalizáció és a szövődmények felderítésére $[5,9,15,16,20$, 21]. Az értékeléskor és a vizsgálatok tervezésekor az adott vizsgálatok korlátait (MR a fémtárgyak vizsgálatára), a beteg megfelelő állapotát és együttmúködési készségét szükséges figyelembe venni. Az intraoperatív diagnosztikában az ultrahang és a C-karos röntgenberendezés hasznos segítséget nyújthat. Számítanunk kell az idegen test időközbeni továbbmozdulására is. Avcu ismertetett esetében az első mütét során az idegen test nem volt elérhető [20]. Santos és Horii eseteiben a laparoszkópos eltávolítást ultrahangvezérelt tályogdrenázs előzte meg [4, 16]. Liu esetében májreszekcióra volt szükség [10]. A laparoszkópos megoldás választását befolyásolhatják a betegnél korábban történt mütétek következtében, valamint az idegen test migrációs folyamata közben kialakuló összenövések. Az idegen test megragadhatósága, kimozdíthatósága és az eltávolítás során okozható további szövődmények lehetősége további korlátozó tényező. A 2. esetünkben a drót visszahajlított vége jelentett ilyen problémát. Ismertetett két esetünkben a diagnosztikus lehetőségek korlátozottak voltak, a beteg állapota mindkét esetben sürgetővé tette a beavatkozást. A hasonló esetekben a mütét közbeni döntések és a tapasztalat jelentősége fokozott.

Anyagi támogatás: A szerzők anyagi támogatásban nem részesültek.

Szerzői munkamegosztás: B. A.: A betegek kezelése, a kézirat megírása. V. T.: A betegek kezelése, a szöveg korrektúrája. T. D.: Képalkotó vizsgálatok elvégzése és prezentálása. B. Zs.: Irodalomkutatás, szövegszerkesztés és korrektúra. A közlemény végleges változatát valamennyi szerző elolvasta és jóváhagyta.

Érdekeltségek: A szerzőknek nincsenek érdekeltségeik.

\section{Irodalom}

[1] McLaughlin RT, Morris JD, Haight C, et al. The morbid nature of the migrating foreign body in the esophagus. J Thorac Cardiovasc Surg. 1968; 55: 188-192.

[2] Ambe P, Weber SA, Schauer M, et al. Swallowed foreign bodies in adults. Dtsch Arztebl Int. 2012; 109: 869-875.

[3] Gül M, Aliosmanoğlu I, Haseven M, et al. Migration of two swallowed foreign bodies to different location in the same case. Ulus Cerrahi Derg. 2014; 30: 228-230.

[4] Santos SA, Alberto SC, Cruz E, et al. Hepatic abscess induced by foreign body: case report and literature review. World J Gastroenterol. 2007; 13: 1466-1470.

[5] Leggieri N, Marques-Vidal P, Cerwenka H, et al. Migrated foreign body liver abscess: illustrative case report, systematic review and proposed diagnostic algorithm. Medicine (Baltimore) 2010; 89: 85-95.

[6] Kuo CL. Management strategies for ingestion of foreign objects in the laryngopharynx. J Oto Rec Surg. 2015; 1: 110.

[7] Saniasiaya J, Mohamad I. Missed hypopharyngeal foreign body: a case report. Egyptian J Ear Throat Allied Sci. 2016; 17: 47-48.

[8] Ziad T, Rochdi Y, Benhoummad O, et al. Retropharyngeal abscess revealing a migrant foreign body complicated by mediastinitis: a case report. Pan Afr Med J. 2014; 19: 125.

[9] Aftab Z, Ali SM, Koliyadan S, et al. Foreign body in the liver: case report and review of literature. Qatar Med J. 2015; 2015: 5.

[10] Liu HJ, Liang CH, Huang B, et al. Migration of a swallowed toothpick into the liver: the value of multiplanar CT. Br J Radiol. 2009; 82: e79-e81.

[11] Tang IP, Singh S, Shoba N, et al. Migrating foreign body into the common carotid artery and internal jugular vein - a rare case. Auris Nasus Larynx 2009; 36: 380-382.

[12] Kumar P, Kumar P, Singh GR. Case report ingested fish bone migration in the neck: a case report. IOSR J Dental Med Sci. 2018; 17 : 43-45.

[13] Lambert A. Abscess of the liver of unusual origin. N Y Med J. $1898 ; 177-178$.

[14] Henderson FF, Gaston EA. Ingested foreign body in the gastrointestinal tract. Arch Surg. 1938; 36: 66-95.

[15] Hasan RM. Sharp foreign body ingestion by a young girl. Alexandria J Med. 2018; 54: 185-187.

[16] Horii K, Yamazaki O, Matsuyama M, et al. Successful treatment of a hepatic abscess that formed secondary to fish bone penetration by percutaneous transhepatic removal of the foreign body: report of case. Surg Today 1999; 29: 922-926.

[17] Roca B. A sewing needle in the liver. South Med J. 2003; 96 : 616-617.

[18] La Mandat-Schultz A, Bonnard A, Belarbi N, et al. Intrahepatic foreign body laparoscopic extraction. Surg Endosc. 2003; 17: 1849.

[19] Bostanci Ö, Idiz UO, Battal M, et al. Case of an intrahepatic sewing needle and review of the literature. Ulus Travma Acil Cerrahi Derg. 2017; 23: 77-80.

[20] Avcu S, Ünal Ö, Özen Ö, et al. A swallowed sewing needle migrating to the liver. North Am J Med Sci. 2009; 1: 193-195.

[21] Riani EB, Tancredi I, Sempoux C, et al. From interventional radiology to laparoscopic liver resection as complementary strategies in the treatment of hepatic abscess caused by ingested foreign bodies. Hepatogastroenterology 2012; 59: 558-560.

(Balázs Ákos dr., Budapest, Üllői út 78., 1082 e-mail: a.balazsdr@gmail.com)

A cikk a Creative Commons Attribution 4.0 International License (https://creativecommons.org/licenses/by/4.0/) feltételei szerint publikált Open Access közlemény, melynek szellemében a cikk bármilyen médiumban szabadon felhasználható, megosztható és újraközölhető, feltéve, hogy az eredeti szerző és a közlés helye, illetve a CC License linkje és az esetlegesen végrehajtott módosítások feltüntetésre kerülnek. (SID_1) 